\title{
Difference in Proximate Content Between Chicken Curry (Kandar Rice) and Chicken Curry (Padang Rice)
}

\author{
Mazarina Devi $^{{ }^{*},}$ Budi Wibowotomo ${ }^{2,}$ Laili Hidayati ${ }^{3,}$ Hashim Fadzil Ariffin ${ }^{4}$ \\ ${ }^{1,2,3}$ Department of Industrial Technology, Faculty of Engineering, Universitas Negeri Malang \\ 4Faculty of Hotel and Tourism Management, Universiti Teknologi MARA, Malaysia \\ "Corresponding author, Email : mazarina.devi.ft@um.ac.id
}

\begin{abstract}
Indonesia and Malaysia have the same family, Malay. This has an effect on the same appearance. This study aims to determine the differences in the content of proximate (protein, fat, crude fiber, water, ash and carbohydrates) contained in chicken curry as one of the side dishes in the Rice and Chicken Curry dishes as one of the side dishes in Padang rice. The research conducted is a quantitative study and analyzed using the Independent Sample T-Test. The highest protein, fat, crude fiber, and ash content in chicken curry (Nasi Kandar), while the highest water and carbohydrate content in chicken curry (Nasi Padang). The conclusion is that although the dishes are the same but there are differences in the nutritional content.
\end{abstract}

Keywords: chicken curry, Nasi Kandar, Nasi Padang, proximate

\section{INTRODUCTION}

Every human being needs to eat for the continuity of their own life. Commonly, consumed food sources come from animals and plants. Indonesia has a traditional food that is still preserved. According to Suprapto (2011:40), traditional food has an important role in the local identity, consumer behaviour, inheritance culture transfer for future generations, and interaction around the world. Each country has a distinctive food that is featured. Food not only serves to meet a person's physical needs, but also serves as a source of nutritional substances that play a role in health. Food as an entry source of nutrient intake in the body is indispensable for everyone. In addition to nutrients needed by the body, to keep the body healthy needed antioxidants that play a role in health.

Each food contains different nutrients and antioxidant compounds, and not all ingredients contains sufficient nutrients. The more diverse food ingredients are eaten, the more healthy our bodies are. One of the traditional food that have variations is nasi Kandar from Malaysia and nasi Padang from Indonesia. Both types of dishes use spices such as turmeric, galangal, ginger, chili, cardamom, lemongrass, etc. Nasi Kandar from Malaysia and nasi Padang from Indonesia is a complete dish served in the form of rice with side dishes and vegetables. Nasi Kandar is well-liked by young people especially in the Penang area (Rais, A.A.R. et.all. 2013).

\section{RESEARCH METHOD}

\subsection{Research Design}

The research methods used in this research are quantitative research methods that are by finding information about the symptoms, clearly defined objectives to be achieved, planning the way of approach, collecting data as an ingredient for making reports. In this study, will measure proximat (protein, ash, water, carbohydrates, fats, and coarse fibre) on Nasi Kandar (Malaysia) and Nasi Padang (Indonesia). Samples of this research are side dish and vegetable of Nasi Kandar and side dish and vegetable of Nasi Padang. The side dish to be analyzed is chicken curry and chicken gulai.

\subsection{Research Data}

In chicken curry dishes from Nasi Kandar (Malaysia) and chicken gulai from Nasi Padang (Indonesia) is a research of proximate content that includes proteins using the semimicro Kjeldahl method, fats using Soxhlet method, Ash using Furnance method, carbohydrates using method by difference, and water using oven method.

\subsection{Research Analysis Data}

In chicken curry dishes from Nasi Kandar (Malaysia) and chicken gulai from Nasi Padang (Indonesia), data is analyzed statistically using the Independent Sample T-Test with a significance of $5 \%$. If the level of significance > 0.05 , it means there is no difference. If the level of significance is $<0.05$ then it means there is a difference. 


\section{RESULTS AND DISCUSSION}

\subsection{Ash Content Analysis of Nasi Kandar and Nasi Padang}

Table 1 Ash Content Data of Chicken Curry and Chicken Gulai

\begin{tabular}{|c|c|c|c|c|}
\hline \multirow{2}{*}{ Sample } & \multicolumn{2}{|c|}{ Repetition } & \multirow{2}{*}{ Total } & \multirow{2}{*}{ Average } \\
\hline & I & II & & \\
\hline Chicken Curry & 7,696 & 7,566 & 15,262 & 7,631 \\
\hline Chicken Gulai & 6,886 & 6,976 & 13,862 & 6,931 \\
\hline
\end{tabular}

The ash content research result of chicken curry in Nasi Kandar has an average of $7.631 \mathrm{gr} / 100 \mathrm{gr}$ samples. The ash contents of chicken gulai in Nasi Padang has an average of $6.931 \mathrm{gr} / 100 \mathrm{gr}$ samples. T-Test analysis results of ash content in chicken curry and chicken gulai showed that the value of significance (0.13) is greater than $\alpha(0.05)$ so that it can be interpreted that the ash content of chicken curry and chicken gulai does not different in the level of significance $5 \%$.
Based on research by Sundari, et all. (2015), fresh chicken meat has a $0.1 \%$ content of ash. The increase in ash content in the chicken gulai from Nasi Padang and in chicken curry from Nasi Kandar wass no different, it is suspected that the ash content does not decrease during heating or cooking. According to the Chayati \& Rananingsih (2010), the chemical and physical treatment has no real effect on minerals. Mineral oxygen may be oxidized to higher valency minerals, but does not affect its nutritional value (Dwi, 2015)

\subsection{Water Content Analysis of Nasi Kandar and Nasi Padang}

Table 2 Water Content Data of Chicken Curry and Chicken Gulai

\begin{tabular}{ccccc}
\hline \multirow{2}{*}{ Sample } & \multicolumn{2}{c}{ Repetition } & \multirow{2}{*}{ Total } & \multirow{2}{*}{ Average } \\
\cline { 2 - 3 } & I & II & & \\
\hline Chicken Curry & 30,040 & 30,114 & 60,154 & 30,077 \\
Chicken Gulai & 33,184 & 33,582 & 66,766 & 33,383 \\
\hline
\end{tabular}

The water content research result of chicken curry in Nasi Kandar has an average of $30.077 \mathrm{gr} / 100 \mathrm{gr}$ samples. The water content of chicken gulai in Nasi Padang has an average of $33.383 \mathrm{gr} / 100 \mathrm{gr}$ samples. T-Test analysis results of water content in chicken curry dish and chicken gulai showed that the value of significance $(0.004)$ is smaller than $\alpha(0.05)$ so that it can be interpreted that the chicken curry water content and chicken gulai different in the level of significance $5 \%$
Water content in chicken curry is lacking, can be caused by the processing process that affects the content of chicken water (Sebayang, 2012:10). The temperature used in the processing also affects the moisture content. The higher the temperature used then the spices and chicken will be more mature, so that the water content can evaporate perfectly (Sulthoniyah, et all., 2013:39). Water content contained in chickens is $0.705 \%$ (Sundari, et all., 2015).

\subsection{Carbohydrate Content Analysis of Nasi Kandar and Nasi Padang}

Table 3 Carbohydrate Content Data of Chicken Curry and Chicken Gulai

\begin{tabular}{|c|c|c|c|c|}
\hline \multirow{2}{*}{ Sample } & \multicolumn{2}{|c|}{ Repetition } & \multirow{2}{*}{ Total } & \multirow{2}{*}{ Average } \\
\hline & $\mathrm{I}$ & II & & \\
\hline Chicken Curry & 8,731 & 8,862 & 17,593 & 8,796 \\
\hline Chicken Gulai & 9,157 & 8,743 & 17,90 & 8,950 \\
\hline
\end{tabular}

The carbohydrate content research result of chicken curry in Nasi Kandar has an average of $8.796 \mathrm{gr} / 100 \mathrm{gr}$ samples. The carbohydrate content of chicken gulai in Nasi Padang has an average of $8.950 \mathrm{gr} / 100 \mathrm{gr}$ samples. T-Test analysis results of carbohydrate content in chicken curry dish and chicken gulai showed that the value of significance $(0.553)$ is greater than $\alpha(0.05)$ so that it can be interpreted that the carbohydrate content of chicken curry and chicken gulai does not different on the level of significance of $5 \%$.
According to Winarno (2004), many carbohydrate content is found in vegetable materials. In the processing of chicken curry and chicken gulai it uses a variety of vegetable ingredients such as spices that have different carbohydrate content. According to Sundari, et all. (2015) processing factors also greatly affect the carbohydrate content. Carbohydrate cooking is required to obtain proper starch digestibility. When the starch is heated, the granules swell and rupture until gelatinized. 


\subsection{Fat Content Analysis of Nasi Kandar and Nasi Padang}

Table 4 Fat Content Data of Chicken Curry and Chicken Gulai

\begin{tabular}{ccccc}
\hline \multirow{2}{*}{ Sample } & \multicolumn{2}{c}{ Repetition } & \multirow{2}{*}{ Total } & \multirow{2}{*}{ Average } \\
\cline { 2 - 3 } & I & II & & \\
\hline Chicken Curry & 28,258 & 28,131 & 56,389 & 28,194 \\
Chicken Gulai & 26,733 & 26,707 & 53,440 & 26,720 \\
\hline
\end{tabular}

The fat content research result of chicken curry in Nasi Kandar has an average of $28,194 \mathrm{gr} / 100 \mathrm{gr}$ samples. The fat content of chicken gulai in Nasi Padang has an average of $26,720 \mathrm{gr} / 100 \mathrm{gr}$ samples. T-Test analysis results of fat content in chicken curry dishes and chicken gulai showed that the value of significance (0002) is smaller than $\alpha(0$, 05) so that it can be interpreted that the fat content of chicken curry and chicken gulai differ in the level of significance $5 \%$.

Fats can be caused by fat content derived from raw chicken, as well as herbs and spices used in fat.
Chicken gulai has a low average rate due to various things, one of which is the cooking process. Cooking process with high temperature will affect the fat content contained in the ingredients. The higher the temperature used, the more intense the fat damage (Sekar, et all., 2009). The occurrence of fat content decrease after cooking due to the fat properties that are not heat resistant, during the cooking process melt the fat even evaporated (volatile) into other components such as flavor (Sundari, 2015).

\subsection{Protein Content Analysis of Nasi Kandar and Nasi Padang}

Table 5 Protein Content Data of Chicken Curry and Chicken Gulai

\begin{tabular}{|c|c|c|c|c|}
\hline \multirow{2}{*}{ Sample } & \multicolumn{2}{|c|}{ Repetition } & \multirow{2}{*}{ Total } & \multirow{2}{*}{ Average } \\
\hline & I & II & & \\
\hline Chicken Curry & 25,276 & 25,326 & 50,602 & 25,301 \\
\hline Chicken Gulai & 24,040 & 23,992 & 48,032 & 24,016 \\
\hline
\end{tabular}

The protein content research result of chicken curry in Nasi Kandar has an average of $25.301 \mathrm{gr} / 100 \mathrm{gr}$ samples. The protein content of chicken gulai in Nasi Padang has an average of $24.016 \mathrm{gr} / 100 \mathrm{gr}$ samples. T-Test analysis results of protein content in chicken curry dish and chicken gulai showed that the value of significance $(0.001)$ is smaller than $\alpha(0.05)$ so that it can be interpreted that the protein content of chicken curry and chicken gulai is distinct from the level of significance $5 \%$.
The increase of protein content in chicken curry is suspected because of the high protein content in raw/fresh, which contributes to the greatest protein content in chicken curry dishes from Nasi Kadar. In addition the cooking temperature also affects the protein content of chicken curry. According to Santiko (2008) The heat and presence of fat, the protein is denatured related to fat and swelling that causes increased protein levels.

\subsection{Crude Fiber Content Analysis of Nasi Kandar and Nasi Padang}

Table 6 Crude Fiber Content Data of Chicken Curry and Chicken Gulai

\begin{tabular}{ccccc}
\hline \multirow{2}{*}{ Sample } & \multicolumn{2}{c}{ Repetition } & \multirow{2}{*}{ Total } & \multirow{2}{*}{ Average } \\
\cline { 2 - 3 } & I & II & & \\
\hline Chicken Curry & 7,723 & 7,731 & 15,454 & 7,727 \\
Chicken Gulai & 5,497 & 5,478 & 10,975 & 5,487 \\
\hline
\end{tabular}

The crude fiber content research result of chicken curry in Nasi Kandar has an average of $7.727 \mathrm{gr} / 100 \mathrm{gr}$ samples. The crude fiber content of chicken gulai in Nasi Padang has an average of $5.487 \mathrm{gr} / 100 \mathrm{gr}$ samples. T-Test analysis results of crude fiber content in chicken curry dish and chicken gulai indicates that the value of significance $(0.000)$ is smaller than $\alpha(0.05)$ so that it can be interpreted that the crude fiber content of chicken curry and chicken gulai differ in the significance of $5 \%$.

According to the research by Raza, et all. (2014) fresh/raw chicken has coarse fiber of $0.080 \%$. While chicken curry has an average high content of crude fiber content. This is because high heating does not affect the reduction in crude fiber levels. According to Damayanthi et all. (2001) food 
fibre serves to prevent constipation, facilitate defecation and able to reduce the risk of stroke, hypertension and heart disease.

\section{CONCLUSION}

The highest protein content has a value of $25.301 \mathrm{~g} / 100 \mathrm{~g}$ found in chicken curry. The highest fat content has a value of $28.194 \mathrm{~g} / 100 \mathrm{~g}$ found in chicken curry. The highest crude fiber content has a value of $7.727 \mathrm{~g} / 100 \mathrm{~g}$ found in chicken curry. The highest water content has a value of $33.383 \mathrm{~g} / 100 \mathrm{~g}$ found in chicken gulai. The highest ash content has a value of $7.631 \mathrm{~g} / 100 \mathrm{~g}$ found in chicken curry. The highest carbohydrate content has a value of $8.950 \mathrm{~g} / 100 \mathrm{~g}$ found in chicken gulai.

\section{ACKNOWLEDGMENT}

This work supported by PNBP research grant of Universitas Negeri Malang Under

Contract No. 20.3.102/UN32.14.1/1t/2019

\section{REFERENCES}

[1] Chayati, I. \& Rananingsih, N. 2010. Efek Pengolahan Terhadap Zat Gizi Pangan. Yogyakarta. Yogyakarta: Universitas Negeri

[2] Damayanthi, E.S., Madanijah., \& Sofia, I.R. 2001. Sifat Fisikokimia dan Daya Terima Tepung Bekatul Padi Awet Sebagai Sumber Serat Makanan. Bogor: Institut Pertanian Bogor.

[3] Dwi, R. 2015. Analisis Proksimat dan Daya Kembang Sereal (Puffed Cereals) Berbahan Dasar Sorgum (sorghum bicolor (L.) Moench). Skripsi. Malang: Jurusan Teknologi Industri, Fakultas Teknik.

[4] Rais, A.A.R., Manan, W., \& Nadiah, W.W. 2013. A Comparative Study of Nasi Kandar Eating Patterns Among Patrons in the Klang Valley and Penang of Malaysia. International Food Research Journal, 20(4), 1789-1797.

[5] Raza, A. Shabbir, M.A., Khan, M.I., \& Suleria, H.A.R. 2014. Effect of Thermal Treatments on the Formation of Heterocyclic Aromatic Amines in Various Meats. Journal of Food Processing and Preservation, 39(4).

[6] Santiko, A. 2008. Pengaruh Substitusi Tepung Terigu dengan Tepung Tempe dan Tepung Bekatul Terhadap Kadar Protein, Kadar Serat dan Daya Terima Kue Kering Kayu Manis. Skripsi. Semarang: Universitas Diponegoro.

[7] Sebayang, L. B. 2012. Perubahan Kandungan Asam Lemak dan Kolesterol Ikan Cobia (Rachycentron canadum) Akibat Pengukusan. Skripsi tidak diterbitkan. Bogor: Fakultas Perikanan dan Ilmu Kelautan, Institut Pertanian Bogor.
[8] Sekar, D.S. \& Syarifa, A.K. 2009. Pengaruh Lama Pemasakan dan Temperatur Pemasakan Kedelai Terhadap Proses Ekstraksi Protein Kedelai untuk Pembuatan Tahu. Skripsi. Semarang: Universitas Diponegoro.

[9] Sulthoniyah, S.T.M., Sulistiyati, T.D., \& Suprayitno, E. 2013. Pengaruh Suhu Pengukusan Terhadap Kandungan Gizi dan Organoleptik Abon Ikan Gabus (Ophichepalus striatus). Jurnal Teknologi Hasil Periklanan, 1(1), 33-45.

[10] Sundari, D., Almasyhuri., \& Lamid, A. 2015. Pengaruh Proses Pemasakan Terhadap Komposisi Zat Gizi Bahan Pangan Sumber Protein. Media Litbangkes, 25(4), 235-242. Dari

http://ejournal.litbang.depkes.go.id/index.php/ MPK/article/viewFile/4590/4127

[11] Suprapto, H. 2011. Pengembangan Keragaman Pangan Lokal di Kalimantan Timur. Jurnal Teknologi Pertanian, 6(2), 40-44.

[12] Winarno, F.G. 2004. Kimia Pangan Dan Gizi. Jakarta: PT. Gramedia Putaka Utama. 